\title{
Educational Policy in a Credit Constrained Economy WITH SKILL HETEROGENEITY
}

\author{
by
}

John Fender and Ping Wang

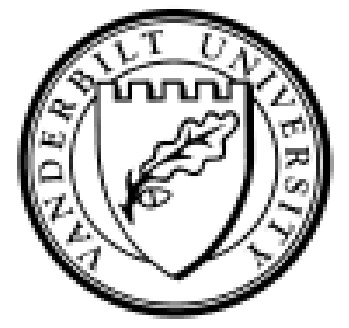

Working Paper No. 01-W33

December 2001

\section{DEPARTMENT OF ECONOMICS \\ VANDERBILT UNIVERSITY \\ NASHVILLE, TN 37235}

www.vanderbilt.edu/econ 


\title{
EDUCATIONAL POLICY IN A CREDIT CONSTRAINED ECONOMY WITH SKILL HETEROGENEITY
}

\author{
John Fender and Ping Wang ${ }^{1}$ \\ University of Birmingham, UK and Vanderbilt University and NBER, USA
}

This Version: December 2001

\begin{abstract}
An overlapping-generations model where agents choose whether to become educated when young is presented. Education enhances productivity, but needs to be financed by borrowing. Because of the possibility of default, lenders may ration credit. We characterize the steady-state equilibrium with and without credit constraints and show that credit constraints are associated with lower education and a lower real interest rate. We then study the role of public policy in remedying the inefficiency which occurs with credit market imperfections and examine whether public education can improve on the constrained equilibrium.
\end{abstract}

Keywords: Education, Credit Constraints, Public Policy.

JEL Classification Codes: E62, H52.

\section{$\underline{\text { Address for Correspondence: }}$}

Professor Ping Wang

Department of Economics

Vanderbilt University

Nashville, TN 37235

U.S.A.

E-mail: ping.wang@vanderbilt.edu; Phone: 615-322-2388; Fax: 615-343-8495. 


\section{INTRODUCTION}

Investment in human capital is of great importance in explaining long-run developments in countries' productive capacities and economic growth. ${ }^{2}$ Education, a source of much human capital accumulation, is often provided by the state or subject to extensive state intervention. An important reason for such intervention is that purely private provision of education would involve market failures. A number of market failures have been discussed in the literature (human capital spillovers in particular have been emphasized); we focus on credit market imperfections because little has been done in an intertemporal general-equilibrium framework to analyze their consequences and to explore the ways in which public policy may provide a remedy.

Credit market imperfections are pervasive in the case of education loans due, in part, to the fact that as human capital does not act as collateral for loans, there is a moral hazard problem in lending to finance education. Evidence that credit constraints affect human capital accumulation abounds. For example, Lazear (1980) and Jacoby and Skoufias (1997) find strong links between financial market imperfections and human capital accumulation in the context of U.S. college and rural Indian child education, respectively. ${ }^{3}$

In this paper, we present a model which considers the general-equilibrium effects of educational choice in a framework which rigorously incorporates moral hazard. We concentrate on the implications of credit market imperfections for education, assuming no failure in the credit market for financing the purchase of physical capital. We model credit market failure as follows: suppose an individual borrows, ostensibly to finance education. The lender cannot guarantee that the borrower will spend the money on education - instead, he may "take the money and run" - which is a classic moral hazard problem. The lender will only lend if he believes the borrower will not default and this generates an incentive compatibility constraint (ICC). Credit constraints emerge endogenously and some agents, who would prefer to borrow, invest in education and repay their loans to having the loans denied, may not be able to borrow. We also consider an alternative setup where the borrower may invest in education and then abscond without repaying the loan.

We embed this framework in an overlapping-generations model where agents live for two periods. 
Agents, endowed with one unit of labor over their lifetime, differ only in their "distaste for education" (or, equivalently, "ability to learn"). Those with the lowest distaste (highest ability) will typically borrow when young to be educated and earn the skilled wage in the second period, when they consume and repay the loan. Those who do not purchase education instead work as unskilled workers when young, saving their earnings to the second period when they consume. Their marginal product, and hence their real wage, is constant and low. Skilled labor complements capital, in that an increase in the employment of skilled workers raises the marginal product of capital. There is a single, homogeneous good which is used either for consumption or investment in physical or human capital. Into this framework, we introduce the possibility of endogenous credit constraints and consider various policy options available to the government, such as an educational subsidy or public provision of education, to remedy the problems caused by credit market imperfections.

Our paper contributes to the literature on educational choice and endogenous credit constraints pioneered by Zeira (1991), Tsiddon (1992) and Galor and Zeira (1993). ${ }^{4}$ We differ from these studies in assuming both an endogenous real interest rate and agents who are heterogeneous both ex ante and ex post. Also, in deciding whether to become educated or not when young, agents are also deciding whether to become borrowers or lenders. Thus, not only is educational choice determined in equilibrium, but the division of the population into borrowers and lenders is endogenous. The latter feature contrasts with virtually all the previous studies except for the trickle-down growth theory of Aghion and Bolton (1997) which is nevertheless very different from ours. ${ }^{5}$

Endogenous determination of borrowers and lenders, endogenous credit constraints and an endogenous real interest rate are crucial to our analysis, and matter significantly in explaining the macroeconomic consequences of credit constraints for education, capital accumulation, and income distribution. ${ }^{6}$ Credit constraints mean that an increased fraction of the population are unskilled workers and lenders. There is substitution of physical capital for skilled workers, the real interest rate decreases, and the skilled wage increases. There are general-equilibrium effects on income distribution: inequality between the skilled and 
unskilled is widened - skilled workers, who are borrowers, benefit, whereas the unskilled, who are lenders, lose from the decline in interest income.

We also discuss educational policy designed to remedy the problem caused by the credit market imperfection. Public education financed by taxing the skilled may be able to restore the unconstrained equilibrium, but only if the government can somehow circumvent the ICC facing private lenders. Since this may be implausible, we consider public education financed by taxing the uneducated. We show that this can ensure the unconstrained equilibrium levels of education and capital accumulation are attained, and that this is optimal with an equally weighted utilitarian social welfare function. Indeed, we give conditions under which public education so financed can be Pareto improving. However, with education financed by taxing the uneducated, education will need to be rationed for optimality. We further examine the effects of an education subsidy, and show that, in our basic model, this can replicate the unconstrained equilibria under the same conditions as government spending can. Yet, we also consider an extension in which government provision of education is superior to government subsidy. Our analysis hence identifies three reasons why the government might be able to improve on the credit-constrained private sector allocation of education. The first is that the government may be better at enforcing contracts than the private sector (though we are skeptical about this). The second is that the government can finance education by taxing those who are not the (direct) beneficiaries, which may be socially optimal and may even be Pareto improving. The third is that the government's ability to choose who is and who is not educated may be a source of welfare gains. We are aware of no comparable discussion of the reasons for government intervention in education in the existing literature.

In Section 2, we present the basic model, while Section 3 analyzes the steady state equilibrium in the absence of credit constraints. Credit market imperfections, and their implications, are studied in Section 4. Section 5 examines educational policies designed to remedy the market failure and Section 6 concludes.

\section{THE MODEL}

Our discrete-time economy is populated with two-period overlapping generations, in which agents 
make just one decision - whether to become educated when young. Individuals are identical, except that they differ in their disutility of acquiring education. The measure of those born in any particular period is normalized to unity. Agents have no initial wealth but supply a unit of labor inelastically in one period of their lives (in the second period if they acquire education; otherwise in the first period). All agents derive utility from secondperiod consumption; apart from this, only the disutility of acquiring education (of the educated) affects utility. There is neither endogenous leisure nor altruism. The utility function is assumed linear (which simplifies the optimal schooling choice and welfare analysis greatly). ${ }^{7}$

The disutility costs incurred in acquiring education, denoted $\alpha$, are assumed to be uniformly distributed in the population between $\epsilon$ and $-\epsilon$, i.e., $\alpha \sim \mathrm{U}(-\epsilon, \epsilon)$. We can interpret $\alpha$ in various ways; for example, it could represent the nonpecuniary cost of acquiring education, or (the inverse of) ability. ${ }^{8}$ In addition, education costs $\theta$ per person in units of goods (we shall sometimes refer to this as the "pecuniary cost of education"). With no initial wealth or bequests, this cost must be financed by borrowing (for the moment, we assume an agent who wishes to borrow has no difficulty doing so, an assumption we relax in Section 4).

An agent born at time t-1 may undertake education to become a skilled worker in the next period ( $\mathrm{t})$ and receive a wage $\mathrm{w}_{\mathrm{H}, \mathrm{t}}$, which is used for loan repayment at a real interest rate $\mathrm{r}_{\mathrm{t}}$ and for consumption. If an agent born at $\mathrm{t}-1$ decides not to become educated in the first period, he works at the unskilled wage $\mathrm{w}_{\mathrm{L}, \mathrm{t}-1}$, saves the proceeds and becomes a lender, receiving interest plus the original value of his capital in the next period to spend on consumption. For the parameters under consideration in the paper (in particular, see Conditions $\mathrm{E}, \mathrm{C}$ and $\mathrm{C}^{\prime}$ in Sections 3 and 4 below), it will always be the case that $\mathrm{r}>0$, hence ruling out dynamic inefficiency. The sequence of actions in the basic framework is shown in Figure 1.

The criterion for an agent born at time $\mathrm{t}-1$ to choose education is hence: $\mathrm{w}_{\mathrm{H}, \mathrm{t}}-\left(1+\mathrm{r}_{\mathrm{t}}\right) \theta-\alpha_{\mathrm{t}-1} \geq(1+$ $\left.\mathrm{r}_{\mathrm{t}}\right) \mathrm{w}_{\mathrm{L}, \mathrm{t}-1}$, where we assume that if an agent is exactly indifferent, he chooses education (inconsequential as such agents are of measure zero). The left-hand side of the expression gives the benefit from education - skilled wage less repayment of the loan and subjective cost of education; the right-hand side is the benefit to remaining 
uneducated - evaluated in terms of second-period consumption. If there is to be a mixture of educated and uneducated workers, there must be a critical value of $\alpha_{\mathrm{t}-1}\left(\right.$ denoted $\left.\alpha_{\mathrm{t}-1}{ }^{*}\right)$ between $-\epsilon$ and $\epsilon$ at which an agent is indifferent between acquiring education and remaining unskilled. That is, $\alpha_{\mathrm{t}-1}{ }^{*}$ solves:

$$
\mathrm{w}_{\mathrm{H}, \mathrm{t}}-\left(1+\mathrm{r}_{\mathrm{t}-1}\right) \theta-\alpha_{\mathrm{t}-1}^{*}=\left(1+\mathrm{r}_{\mathrm{t}-1}\right) \mathrm{w}_{\mathrm{L}, \mathrm{t}-1} \text {. }
$$

Agents of type $\alpha_{\mathrm{t}-1} \in\left[-\epsilon, \alpha_{\mathrm{t}-1}{ }^{*}\right]$ become educated, whereas those with $\alpha_{\mathrm{t}-1} \in\left(\alpha_{\mathrm{t}-1}{ }^{*}, \epsilon\right]$ remain uneducated. We assume that $\theta>\epsilon$, so that education is costly for everyone.

The single good in the economy is produced either by unskilled workers or by skilled workers combining with capital, so we can regard the economy as comprised of two sectors: $Y_{t}=Y_{L, t}+Y_{H, t}$, where $Y_{t}$ is total output at time $\mathrm{t}$, and $\mathrm{Y}_{\mathrm{i}, \mathrm{t}}(\mathrm{i}=\mathrm{L}, \mathrm{H})$ is the output of sector $\mathrm{i}$ at time $\mathrm{t}$. Let $\ell_{\mathrm{i}, \mathrm{t}}$ represent aggregate employment in sector $\mathrm{i}$ in period $\mathrm{t}$. In the benchmark model, we assume that unskilled labor has a constant, low marginal product $\mathrm{v}>0$ and does not combine with capital to produce output: $\mathrm{Y}_{\mathrm{L}, \mathrm{t}}=\mathrm{v} \ell_{\mathrm{L}, \mathrm{t}}$. Skilled labor combines with capital in a constant returns Cobb-Douglas production function: $Y_{\mathrm{H}, \mathrm{t}}=\ell_{\mathrm{H}, \mathrm{t}}^{\beta} \mathrm{K}_{\mathrm{t}}^{1-\beta}=\ell_{\mathrm{H}, \mathrm{t}} \mathrm{k}_{\mathrm{t}}^{1-\beta}$, where $\mathrm{K}_{\mathrm{t}}$ is capital at the beginning of period $\mathrm{t}$ and $\mathrm{k}_{\mathrm{t}} \equiv \mathrm{K}_{\mathrm{t}} / \ell_{\mathrm{H}, \mathrm{t}}$ is the capital-skilled labor ratio (which we will henceforth describe as the capital-labor ratio). We assume capital-skilled labor complementarity, an assumption with much empirical support (e.g., Bergström and Panas 1992). ${ }^{9}$ Output at date $\mathrm{t}$ is thus given by: $\mathrm{Y}_{\mathrm{t}}=\mathrm{v} \ell_{\mathrm{L}, \mathrm{t}}+\ell_{\mathrm{H}, \mathrm{t}} \mathrm{k}_{\mathrm{t}}^{1-\beta}$. With competitive factor markets, factor prices are determined by the usual conditions:

$$
\begin{gathered}
\mathrm{w}_{\mathrm{L}, \mathrm{t}}=\mathrm{v} \\
\mathrm{w}_{\mathrm{H}, \mathrm{t}}=\beta \mathrm{k}_{\mathrm{t}}^{1-\beta} \\
\mathrm{r}_{\mathrm{t}}=(1-\beta) \mathrm{k}_{\mathrm{t}}^{-\beta}-\delta,
\end{gathered}
$$

where $\delta$ is depreciation of capital. Let $\mathrm{x}_{\mathrm{t}-1}$ denote the proportion of the generation born at time $\mathrm{t}-1$ who become educated. It follows that in labor market equilibrium, we have:

$$
\mathrm{x}_{\mathrm{t}-1}=\ell_{\mathrm{H}, \mathrm{t}} ; \quad 1-\mathrm{x}_{\mathrm{t}-1}=\ell_{\mathrm{L}, \mathrm{t}-1} \text {. }
$$

With a uniform distribution of disutilities of education, we obtain: $\mathrm{x}_{\mathrm{t}-1}=\left(\alpha_{\mathrm{t}-1}{ }^{*}+\epsilon\right) /(2 \epsilon)$, or,

$$
\alpha_{\mathrm{t}-1}^{*}=-\epsilon+2 \epsilon \mathrm{x}_{\mathrm{t}-1}
$$


which gives a linear relationship between the proportion of the labor force which becomes educated and the critical disutility cost of education.

Finally, to complete the specification of the model, we turn to the goods market. The capital evolution equation can be written as:

$$
\mathrm{K}_{\mathrm{t}+1}-(1-\delta) \mathrm{K}_{\mathrm{t}}=\mathrm{v} \ell_{\mathrm{L}, \mathrm{t}}+\ell_{\mathrm{H}, \mathrm{t}} \mathrm{k}_{\mathrm{t}}^{1-\beta}-\mathrm{C}_{\mathrm{H}, \mathrm{t}}-\mathrm{C}_{\mathrm{L}, \mathrm{t}}-\theta \mathrm{x}_{\mathrm{t}},
$$

where $\mathrm{C}_{\mathrm{i}, \mathrm{t}}(\mathrm{i}=\mathrm{H}, \mathrm{L})$ is the aggregate consumption of group $\mathrm{i}$ at time $\mathrm{t}$ :

$$
\begin{aligned}
\mathrm{C}_{\mathrm{H}, \mathrm{t}} & =\left[\mathrm{w}_{\mathrm{H}, \mathrm{t}}-\left(1+\mathrm{r}_{\mathrm{t}}\right) \theta\right] \mathrm{x}_{\mathrm{t}-1}, \\
\mathrm{C}_{\mathrm{L}, \mathrm{t}} & =\mathrm{w}_{\mathrm{L}, \mathrm{t}-1}\left(1+\mathrm{r}_{\mathrm{t}}\right)\left(1-\mathrm{x}_{\mathrm{t}-1}\right) .
\end{aligned}
$$

The left-hand side of equation (5) gives the net change in capital from period t-1 to t plus depreciation (i.e., total spending on investment). The right-hand side gives total output, less consumption by the two groups, less spending on education for those born in period $t$.

\section{UNCONSTRAINED EQUILIBRIUM}

We now introduce our unconstrained equilibrium concept:

Definition 1: An unconstrained non-degenerate steady-state equilibrium (NSSE) is a tuple of positive quantities $\left\{C_{L}, C_{H}, \ell_{L}, \ell_{H}, k, Y, x\right\}$, a tuple of positive prices $\left\{w_{L}, w_{H}, r\right\}$ and a critical value $\alpha^{*} \in(-\epsilon, \epsilon)$, all of which are constant over time, such that

(i) schooling is optimal: type $\alpha \in\left[-\epsilon, \alpha^{*}\right]$ chooses to be educated and type $\alpha \in\left(\alpha^{*}, \epsilon\right]$ remains uneducated, where $\alpha^{*}$ satisfies (1);

(ii) consumption of skilled and unskilled workers is determined by $(6 a)$ and (6b), respectively;

(iii) factor demands are given by $(2 a)-(2 c)$;

(iv) allocation of labor across sectors and labor market equilibrium are given by (3) and (4);

(v) goods market equilibrium is achieved as in (5).

As all variables take on their steady-state values, we drop time subscripts. 
Our solution procedure is to reduce the steady-state relationships of the model to two equations in two unknowns, $\mathrm{x}$ (the fraction of population which becomes educated) and $\mathrm{k}$ (the capital-labor ratio). One, which we describe as the endogenous schooling locus (denoted by SS), relates the value of $\mathrm{x}$ which results from everyone making his optimal schooling decision to the capital-labor ratio $\mathrm{k}$. The second, the goods market equilibrium locus (denoted by EE), gives the combinations of $\mathrm{x}$ and $\mathrm{k}$ such that the goods market is in equilibrium. Using these loci, the steady-state equilibrium values of $\mathrm{x}$ and $\mathrm{k}$ are determined. Substituting these into (2)-(4), we obtain the steady-state equilibrium values of factor prices $\left(\mathrm{w}_{\mathrm{L}}, \mathrm{w}_{\mathrm{H}}\right.$ and $\mathrm{r}$ ), labor demand in each sector $\left(\ell_{\mathrm{L}}\right.$ and $\left.\ell_{\mathrm{H}}\right)$ and the critical value of the disutility cost of education $\left(\alpha^{*}\right)$. Then, utilizing (6a) and (6b), we obtain steady-state equilibrium consumption $\left(\mathrm{C}_{\mathrm{L}}\right.$ and $\left.\mathrm{C}_{\mathrm{H}}\right)$. By definition, steady-state capital is $\mathrm{K}=\mathrm{xk}$. Thus, our main task is to determine $\mathrm{x}$ and $\mathrm{k}$ using the $\mathrm{SS}$ and $\mathrm{EE}$ loci; the remaining endogenous variables can then be determined recursively.

To derive the SS locus, we substitute (2) and (4) into (1), assuming a steady state, to obtain:

$$
\beta \mathrm{k}^{1-\beta}=\epsilon(2 \mathrm{x}-1)+\left[1+(1-\beta) \mathrm{k}^{-\beta}-\delta\right](\theta+\mathrm{v}),
$$

which may be rewritten in a form with factor prices:

$$
\mathrm{w}_{\mathrm{H}}(\mathrm{k})=\epsilon(2 \mathrm{x}-1)+(1+\mathrm{r}(\mathrm{k}))(\theta+\mathrm{v}) \text {. }
$$

The locus has a slope of $\beta(\mathrm{r}+\delta)[(\theta+\mathrm{v}) / \mathrm{k}+1] /(2 \epsilon)>0$ in $(\mathrm{k}, \mathrm{x})$ space and a horizontal intercept of $\mathrm{k}_{\min }>0$ (see Figure 2). A higher k makes education more desirable for two reasons: it raises the skilled wage and reduces the real interest rate $\left(\mathrm{dw}_{\mathrm{H}} / \mathrm{dk}>0\right.$ and $\left.\mathrm{dr} / \mathrm{dk}<0\right)$, so from $(8)$ an increase in $\mathrm{x}$ is needed for the increase in $\mathrm{k}$ to be compatible with individual rationality in educational choice. As $\mathrm{k}$ approaches zero, the skilled wage also tends to zero but the unskilled wage remains at $\mathrm{v}>0$. Given $\theta>\epsilon$, acquiring education is costly for all agents and the skilled wage has to be above the unskilled wage before education is strictly positive. At $\mathrm{k}_{\min }$, the skilled wage is such that the agent with the lowest marginal disutility cost of education is indifferent whether to acquire education or not.

To obtain the EE locus, we combine equations (2) and (4)-(6), impose the steady-state condition and 
manipulate, yielding: $\delta x k=(1-\beta) x^{1-\beta}+\left[(1-\beta) k^{-\beta}-\delta\right][(\theta+v) x-v]$, which, providing $r>0$, simplifies to:

$$
\mathrm{x}(\mathrm{k}+\theta)=\mathrm{v}(1-\mathrm{x}) .
$$

This states that the savings of the unskilled (the right-hand side) comprise capital and education loans (the lefthand side). The locus has a negative slope of $-(\theta+v+k) / x$ in $(k, x)$ space and a vertical intercept of $x_{\max }=v /(\theta$ $+\mathrm{v})<1$, with the horizontal axis as the asymptote as $\mathrm{k}$ tends to infinity (see Figure 2). Intuitively, an increase in $\mathrm{x}$ means less savings are generated, while more are invested in education. So capital accumulation must fall to maintain goods market equilibrium.

The system is illustrated in Figure 2 where point E indicates the (unconstrained) steady-state equilibrium. To ensure the existence of an NSSE solution for $(k, x)$, we assume:

Condition E: (Existence of the Unconstrained Equilibrium) $\theta>\mathrm{v}$.

When $\theta>\mathrm{v}$, the SS locus must lie above the EE locus at $\mathrm{k}=\mathrm{k}_{\max } \equiv[(1-\beta) / \delta]^{1 / \beta}$, which corresponds to the case of $\mathrm{r}=0 .{ }^{10}$ However, when $\mathrm{k}=\mathrm{k}_{\min }\left(<\mathrm{k}_{\max }\right)$, the EE locus lies above the SS locus. The SS locus slopes upward, the EE locus downward, and both curves are continuous, so they must cross once. It follows that under Condition $\mathrm{E}$, there is a unique NSSE solution for $(\mathrm{k}, \mathrm{x})$, in which $\mathrm{k} \in\left(\mathrm{k}_{\min }, \mathrm{k}_{\max }\right)$ and $\mathrm{x} \in(0, \mathrm{v} /(\theta+\mathrm{v}))$. Then, from (2)-(4), (6a) and (6b), the NSSE solution for the other endogenous variables is uniquely determined.

Theorem 1: (Existence of NSSE) Under Condition E, there is a unique non-degenerate steady-state equilibrium in which a nontrivial fraction of high- $\alpha$ agents become unskilled workers and a nontrivial fraction of low- $\alpha$ agents undertake education and become skilled workers.

It is possible to carry out some comparative statics analysis, computing the effects of various parameter changes on $\mathrm{x}$ and $\mathrm{k}$, illustrated by appropriate changes in the SS and/or EE loci. However, these results are straightforward and not of great interest, and therefore omitted. 


\section{CREDIT CONSTRAINED EQUILIBRIUM}

In the previous section we assumed there to be no problem in borrowing to finance education. In reality, credit markets are notoriously imperfect and borrowing for many purposes is often difficult and sometimes impossible, giving rise to credit constraints. To generate such constraints endogenously, we focus on the presence of the moral hazard problem. ${ }^{11}$ The basic idea is to capture the moral hazard story of Banerjee and Newman (1993): “[an agent may] attempt to avoid his obligations by fleeing from his village, albeit at the cost of lost collateral" (p. 280). In our model, the borrower has the option of "taking the money and running" (or "absconding"), which means that he will not repay the loan. ${ }^{12}$ There are costs to absconding, though (the absconder may be caught and punished); lending will take place if such costs exceed the benefits.

We consider two ways to model this moral hazard problem. The first is where the lender can ensure that a borrower who obtains a skilled job repays the loan (by, for example, an automatic payroll deduction), but cannot ensure that the borrower actually spends the money on education rather than absconding with the loan. We analyze the model which incorporates this assumption, which we describe as "the basic model," in Section 4.1 below. A second approach (following Sappington 1983 and Hart and Moore 1994) is to assume that the lender can ensure that the money lent is spent on education, but cannot force the borrower to repay the loan (although penalties will be imposed on him if he defaults). The borrower hence has two choices: whether to borrow and invest in education and, if he has done so, whether to repay the loan. We describe this as "an alternative approach to modeling moral hazard," and derive its implications in Section 4.2. below. The basic model is more appropriate if a worker is required to disclose information to become employed and reveal information while employed, or if the penalties that can be imposed on an employed worker is higher.

\subsection{The Basic Model}

In the basic model, the lender cannot ensure that the borrower will invest the money rather than take the money and run. The lender will therefore lend only if he knows that the borrower will use the money to invest in education rather than abscond, and for this reason may ration the amount he is willing to lend. Thus, 
the ICC states that a borrower will not abscond if and only if the benefit from education net of loan repayments exceeds the benefit from absconding, which is the amount of money lent, evaluated in the second period, less costs of default in units of consumption goods (denoted $\pi)$ : $w_{H^{-}}-(1+r) \theta-\alpha \geq(1+r) \theta-\pi$, where we assume, again inconsequentially, that an agent who is exactly indifferent whether to abscond or not, chooses not to do so. The costs of default represent the expected values of penalties which defaulters may suffer, or the net resources used by defaulters in absconding. ${ }^{13}$

We assume that lenders can observe the disutility of education $(\alpha)$ of each potential borrower. ${ }^{14}$ Thus, there is a critical value of $\alpha$, denoted $\alpha^{*}\left(\mathrm{x}^{\mathrm{c}}\right)$, at which a borrower is indifferent between using the loan to educate himself and absconding, where $\mathrm{x}^{\mathrm{c}}$ is the corresponding fraction of the educated labor force under credit constraints, satisfying:

$$
\mathrm{w}_{\mathrm{H}}-(1+\mathrm{r}) \theta-\alpha^{*}\left(\mathrm{x}^{\mathrm{c}}\right)=(1+\mathrm{r}) \theta-\pi
$$

Therefore, individuals with $\alpha \leq \alpha^{*}\left(\mathrm{x}^{\mathrm{c}}\right)$ want to, and are able to, borrow to finance education. Those with $\alpha>\alpha^{*}\left(\mathrm{x}^{\mathrm{c}}\right)$ are unable to borrow, as were they to do so, they would not repay the loan. Lenders realize this and hence do not lend to these individuals. This is so even though there would be mutual gains if the money were lent and spent on education, which can be seen by noting that the criterion for education to be individually worth undertaking can be satisfied for an individual with an $\alpha$ greater than $\alpha^{*}\left(\mathrm{x}^{\mathrm{c}}\right)$. Note that in this model, default will not be observed in equilibrium, although its possible occurrence is of crucial importance in generating some of our results.

It might be asked whether the financial contracts we postulate are optimal. We can argue that indeed they are, provided financial intermediaries are competitive (which we implicitly assume). Consider the alternative that conditions repayments on observable features of the borrowers, that is, $\alpha$. It is obvious that a monopoly lender would do this (those with lower $\alpha$ 's being required to repay more). However, with competition, this would be impossible - if a lender offered a financial contract to a borrower with an interest rate greater than $r$, he would be undercut by another lender. We are hence able to endogenize the credit constraint, and in 
this way improve upon the exogenous borrowing constraints assumption commonly used in the literature (examples are Hare and Ulph 1981, Azariadis and Smith 1993 and De Gregorio 1996). In our model, we say that endogenous credit constraints exist if there is a set of agents of positive measure with $\alpha>\alpha^{*}\left(\mathrm{x}^{\mathrm{c}}\right)$ for whom schooling is desirable. Using the steady-state version of (4), we can rearrange (10) to obtain the following credit constraint locus (denoted CC):

$$
\mathrm{w}_{\mathrm{H}}=\epsilon(2 \mathrm{x}-1)+2(1+\mathrm{r}) \theta-\pi
$$

Accordingly, the definition of steady-state equilibrium becomes:

Definition 2: A non-degenerate credit constrained steady-state equilibrium (NCCSSE) is a tuple of positive quantities $\left\{C_{L}, C_{H}, \ell_{L}, \ell_{H}, k, Y, x\right\}$, a tuple of positive prices $\left\{w_{L}, w_{H}, r\right\}$ and a critical value $\alpha^{*}\left(x^{c}\right) \in(-\epsilon, \epsilon)$, all of which are constant over time, such that (ii)-(vi) in Definition 1 are met and

(i) $\quad$ the economy is credit constrained: type $\alpha \in\left[-\epsilon, \alpha^{*}\left(x^{c}\right)\right]$ receive education loans and are educated, type $\alpha \in\left(\alpha^{*}\left(x^{c}\right), \epsilon\right]$ are denied loans and remain uneducated, where $x^{c}$ solves (11); moreover, there is a set of agents of positive measure with $\alpha>\alpha^{*}\left(x^{c}\right)$ for whom $w_{H,}-\alpha \geq(1+r)(\theta+v)$.

It is useful to apply duality properties to establish and characterize the constrained equilibrium. From (2b) and (2c), we get the factor price frontier relationship: $[(\mathrm{r}+\delta) /(1-\beta)]^{1-\beta}\left[\mathrm{w}_{\mathrm{H}} / \beta\right] \beta=1$, which yields $\mathrm{w}_{\mathrm{H}}=\mathrm{W}(\mathrm{r})$ $=\beta[(1-\beta) /(\mathrm{r}+\delta)]^{(1-\beta) / \beta}$ (obviously, $\mathrm{W}_{\mathrm{r}}<0$ and $\mathrm{W}_{\mathrm{rr}}>0$ ). The capital-labor ratio can therefore be expressed as: $\mathrm{k}=-\mathrm{W}_{\mathrm{r}}(\mathrm{r})=[(1-\beta) /(\mathrm{r}+\delta)]^{1 / \beta}$. This can be substituted into (9) to obtain: $\mathrm{x}=\mathrm{v} /\left[(\theta+\mathrm{v})-\mathrm{W}_{\mathrm{r}}(\mathrm{r})\right]$, which is increasing in $r$. Using this expression, together with (8) and (11), respectively, gives:

$$
\begin{aligned}
& \Psi^{\mathrm{u}}(\mathrm{r}) \equiv \Psi(\mathrm{r})-(1+\mathrm{r})(\theta+\mathrm{v})=0 \\
& \Psi^{\mathrm{c}}(\mathrm{r}) \equiv \Psi(\mathrm{r})-[2(1+\mathrm{r}) \theta-\pi]=0
\end{aligned}
$$

where $\Psi(r) \equiv W(r)+\epsilon\left\{1-2 v /\left[(\theta+v)-W_{r}(r)\right]\right\}$ satisfies $\Psi_{r}<0$. These equations pin down the unconstrained and constrained steady-state equilibrium values of r, which are $\left(\Psi^{u}\right)^{-1}(0)$ and $\left(\Psi^{c}\right)^{-1}(0)$, respectively. It is clear that both $\Psi^{\mathrm{u}}(\mathrm{r})$ and $\Psi^{\mathrm{c}}(\mathrm{r})$ are monotone decreasing in $\mathrm{r}$. In order for a constrained steady-state equilibrium 
associated with a positive real interest rate to exist, one requires (i) the unconstrained equilibrium violates the ICC (i.e., $\Psi^{\mathrm{c}}(\mathrm{r})<0$ at the value of $\mathrm{r}$ satisfying $\left.\Psi^{\mathrm{u}}(\mathrm{r})=0\right)$ and (ii) the value of $\mathrm{r}$ solving $(12 \mathrm{~b})$ is positive (i.e., $\Psi^{c}(0)>0$, imposed for a fair comparison between the unconstrained and constrained equilibrium). That is, the following condition must be met: ${ }^{15}$

Condition C: (Credit Constrained Equilibrium) (i) $\left[1+\left(\Psi^{u}\right)^{-1}(0)\right](\theta-v)>\pi$ and (ii) $\beta\left(k_{\max }\right)^{1-\beta}+\pi>2 \theta$.

Recall that Condition E requires $\theta-\mathrm{v}>0$, which holds true under Condition C (since Part (i) and Part (ii) together imply $\left(\Psi^{\mathrm{u}}\right)^{-1}(0)>\left(\Psi^{\mathrm{c}}\right)^{-1}(0)>0$ and hence $\left.\theta-\mathrm{v}>\pi /\left[1+\left(\Psi^{\mathrm{u}}\right)^{-1}(0)\right]>0\right)$. Straightforward total differentiation of (12a) and (12b) suggests that Part (i) of Condition is met if the unskilled wage or the absconding cost is sufficiently small and that Part (ii) of Condition $\mathrm{C}$ is true if the rate of depreciation is low enough (so $\mathrm{k}_{\max }$ is sufficiently large). We can now establish:

Theorem 2: (Existence of NCCSSE) Under Conditions E and C, there is a unique non-degenerate credit constrained steady-state equilibrium in which a nontrivial fraction of high- $\alpha$ agents choose to work as unskilled, a nontrivial fraction of intermediate- $\alpha$ agents desire schooling but are denied credit, and a nontrivial fraction of low- $\alpha$ agents obtain loans and undertake education.

Note that the uniqueness is ensured by the property that $\Psi^{\mathrm{c}}(\mathrm{r})$ is monotone decreasing in $\mathrm{r}$. To characterize the NCCSSE, we again rely on a system in $(\mathrm{k}, \mathrm{x})$. Under Condition $\mathrm{C}$, loans will not be made to finance the unconstrained level of education and the equilibrium is credit constrained. Substitution for $\mathrm{w}_{\mathrm{H}}$ and $\mathrm{r}$ from $(2 \mathrm{~b})$ and $(2 \mathrm{c})$ into (11) yields the CC locus in $(\mathrm{k}, \mathrm{x})$ space:

$$
\beta \mathrm{k}^{1-\beta}=\epsilon(2 \mathrm{x}-1)+2\left[1+(1-\beta) \mathrm{k}^{-\beta}-\delta\right] \theta-\pi,
$$

Its slope, $\beta(\mathrm{r}+\delta)(2 \theta / \mathrm{k}+1) / 2 \epsilon$, is positive and greater than the slope of the SS locus described by (7) under Condition C. Intuitively, an increase in k relaxes the ICC as it raises the skilled wage (increasing the return to education) and reduces the interest rate (decreasing the amount that needs to be repaid and also the benefits 
from absconding). Lenders are willing to lend to individuals with higher $\alpha$ 's and hence $\mathrm{x}$ rises.

Figure 3 depicts the three loci, where the SS and CC loci intersect at A and incentive compatibility is satisfied for all $(\mathrm{k}, \mathrm{x})$ lying on or below the CC locus (so the segment of the SS locus above point A remains effective). Comparing points $\mathrm{E}$ and $\mathrm{C}$ and using (2b) and (2c), we conclude:

Proposition 1: (Constrained vs. Unconstrained Equilibrium) The constrained equilibrium is Pareto inefficient whereas the unconstrained equilibrium is Pareto efficient. In the steady state, an economy with credit constraints is associated with a lower level of education, a higher capital-labor ratio, a lower real interest rate, and a greater skilled wage rate, than is its absence.

Proof: All proofs are in the Appendix.

By Pareto inefficiency we mean that a relaxation of the ICC would enable everyone to become better off in the presence of lump-sum taxes and transfers. The Pareto inefficiency of the constrained equilibrium is unsurprising, as credit constraints limit some agents' opportunities to become educated despite its desirability. That credit constraints mean a lower real interest rate corroborates Azariadis and Smith (1993), although the underlying mechanism is different. In their pure exchange model, adverse-selection induced credit constraints raise savings, hence reducing the real interest rate. In our production economy where the uneducated are savers, moral-hazard induced credit constraints imply education falls and some agents switch from borrowing to lending. For this reason savings rise and, with capital-skilled labor complementarity, the marginal product of capital and real interest rate fall. ${ }^{16}$ This result differs from the investment loan models, such as Aghion and Bolton (1997), in which credit constraints limit investment, leading to a higher marginal product of capital and real interest rate. An important implication of this theoretical finding is that the effect of credit constraints on the real rate of interest depends crucially on whether the rationing applies to loans to finance investment in human or physical capital.

Importantly, credit constraints also generate distributional effects. Those excluded from education 
because of credit constraints suffer, and all the unskilled lose because of the lower real interest rate. Those who can still borrow to purchase education gain in two ways from credit constraints: the skilled wage rises and the real interest rate falls. So the presence of credit constraints not only has efficiency costs by distorting educational choice, but also widens the gap between the skilled and the unskilled. In contrast, in models with an exogenous real interest rate, the distributional effect of credit constraints via the latter channel is absent.

Proposition 2: (Inequality) The presence of credit constraints widens inequality between the skilled and the unskilled.

Straightforward comparative static analysis yields:

Proposition 3: (Characterization of the NCCSSE) The non-degenerate credit constrained steady-state equilibrium possesses the following properties:

(i) a mean-preserving spread of the distribution of the disutility cost of education (i.e., a larger $\epsilon$ ) encourages education and discourages capital accumulation;

(ii) an increase in the productivity (wage) of the unskilled (v) raises both the capital-labor ratio and the level of education;

(iii) an increase in the pecuniary education $\operatorname{cost}(\theta)$ reduces the proportion of the population educated and has an ambiguous effect on the capital-labor ratio;

(iv) an increase in the absconding cost $(\pi)$ increases the proportion of the population educated and decreases the capital-labor ratio.

These changes can be illustrated diagrammatically. In Figure 3, the constrained equilibrium is where the CC and EE loci intersect (the SS locus is irrelevant in the constrained equilibrium). The change in $\epsilon$ shifts the $\mathrm{CC}$ locus leftwards provided $\mathrm{x}<1 / 2$ (which holds true under Condition $\mathrm{E}$ ). The explanation is that, since the majority of the population is unskilled, an increase in ex ante heterogeneity (higher $\epsilon$ ) reduces the marginal 
disutility cost of education of the person who is just rationed out of an education loan. The ICC is relaxed, represented by a leftward shift in the CC curve. The EE curve is unaltered - so $\mathrm{k}$ falls and $\mathrm{x}$ rises.

An increase in the productivity/wage of the unskilled (v) does not affect the CC locus, but does shift the EE locus outwards. More savings are generated; there is more capital accumulation and education rises. The effects of an increase in the pecuniary cost of education $(\theta)$ on $\mathrm{x}$ is negative whereas its effect on k could go in either direction. Diagrammatically, the CC locus shifts rightwards (since more must now be lent for education purposes, the ICC is tightened) and the EE locus inwards (since education is more expensive, less savings are available for capital accumulation). Finally, an increase in the absconding cost $(\pi)$ merely relaxes the severity of credit constraints, inducing a leftward shift in the CC locus without affecting the EE locus. As a result, more agents become educated, leading to a reduction in savings and a lower capital-labor ratio.

\subsection{An Alternative Approach to Modeling Moral Hazard}

Under our alternative setup, the lender can ensure that the money lent is invested, but cannot appropriate the return; the borrower may invest in education and become a skilled worker without repaying the loan, although this has a cost. The ICC is therefore modified to: $\mathrm{w}_{\mathrm{H}}-(1+\mathrm{r}) \theta-\alpha \geq \mathrm{w}_{\mathrm{H}}-\alpha-\pi$, or, simply, $\pi$ $\geq(1+\mathrm{r}) \theta$. Substituting $(2 \mathrm{c})$ into the constraint with equality yields a modified CC locus:

$$
\left[1+(1-\beta) \mathrm{k}^{-\beta}-\delta\right] \theta=\pi \text {. }
$$

which determines a critical value of the capital-labor ratio, $\mathrm{k}_{\mathrm{IC}}=[(1-\beta) /(\pi / \theta-1+\delta)]^{1 / \beta}$. When $\mathrm{k} \geq \mathrm{k}_{\mathrm{IC}}$ the real interest rate is such that absconding is not profitable, thus ensuring incentive compatibility. This constraint is analogous to the limited liability constraint (PAii) in Sappington (1983, p. 6).

We illustrate the constrained and unconstrained equilibria also in Figure 3. A major difference from the basic model is that the CC locus is now vertical in (k, $\mathrm{x})$ space (referred to as $\mathrm{CC}^{\prime}$ in the figure). The following condition ensures the existence of a credit-constrained equilibrium associated with $r>0$ :

Condition $\mathbf{C}^{\prime}$ : (Credit constraints) $\beta[(1-\beta) /(\pi / \theta-1+\delta)]^{(1-\beta) / \beta}>\pi / \theta>1$. 
Theorem 2': (Existence of NCCSSE) Under Conditions E and $C^{\prime}$, there is a unique non-degenerate credit constrained steady-state equilibrium.

The first inequality of Condition $\mathrm{C}^{\prime}$ guarantees that the ICC is binding (so point $\mathrm{C}$ is to the right of point $\mathrm{E}$ ). The second inequality of Condition $\mathrm{C}^{\prime}$ implies the constrained equilibrium (point $\mathrm{C}^{\prime}$ ) is accompanied by a positive real interest rate.

By comparing the constrained and unconstrained equilibria, one can easily see that credit constraints result in a lower level of education, a higher capital-labor ratio, a lower real interest rate, and a greater skilled wage in the steady state, as in the benchmark model. However, the comparative statics differ in two respects: (i) a mean-preserving spread of the distribution of $\alpha$ 's will no longer have any influence on the steady-state level of education or capital-labor ratio; (ii) the effects of the opportunity and pecuniary costs of education on the capital-labor ratio will change (while $\mathrm{k}$ is independent of $\mathrm{v}$, an increase in $\theta$ raises the capital-labor ratio unambiguously). However, the steady-state response of education to changes in the pecuniary cost of education and the effect of a change in the cost of absconding remain qualitatively unchanged.

\section{PUBLIC POLICY}

We now consider what public policy can do to remedy the problem caused by credit market imperfections, namely that some individuals for whom the private (and social) return to education exceeds the relevant interest rate cannot obtain finance. We assume the government cannot do anything which directly impinges upon the source of the problem, namely that there is no way in which borrowers can commit to repaying loans. We consider several policies: one is whether government provision of education financed by taxing the educated can improve on the constrained equilibrium. The second is whether there is a case for government provision of education financed, instead, by taxing the uneducated. The third is whether a subsidy to education is preferable to government provision.

In order to consider the question, we need to specify the government objective function. We use the 
equally weighted utilitarian social welfare function (recall that the individual utility function is linear):

$$
\Omega(\mathrm{x}) \equiv \mathrm{C}_{\mathrm{H}}(\mathrm{x})+\mathrm{C}_{\mathrm{L}}(\mathrm{x})-\epsilon \mathrm{x}(\mathrm{x}-1) .
$$

The first two terms are total consumption of the skilled and unskilled, respectively. The last term subtracts the total disutility of education of the educated. ${ }^{17}$ Technically, (14) is consistent with the standard periodic (or period-by-period) social welfare function in the overlapping generations literature where all endogenous variables are evaluated at their steady-state values and when there is an initial old generation subject to government reallocation. ${ }^{18}$ Given the infinite number of agents, one cannot sum everyone's utility without using an arbitrary social discount factor. Thus, a periodic social welfare function evaluated in the steady state is the least controversial choice. In the social optimum, the government chooses $x$ to maximize (14), subject to the government budget constraint and the resource constraint (i.e., the EE locus). By relevant substitution, the maximization problem can be defined in terms of $\mathrm{x}$ (i.e., $\mathrm{k}$ can be eliminated).

\subsection{Public Education Financed by Taxing the Educated}

First, assume government spending is financed by a wage tax on the educated. It is important to specify how the transition is made from private to public provision. If the first old generation to be taxed is also repaying private education loans, it will be made worse off by the introduction of public education and this might be considered unfair. Instead, we consider an alternative way of introducing the policy, namely, that when it is introduced it is financed by bonds sold to the uneducated. In each subsequent period, the old educated are taxed to finance the interest on the bonds and the education provided to the younger generation.

More precisely, suppose that up to and including period 0 , the economy is in a steady state with private provision of education. In period 1, the government introduces public education and private provision of education ceases. In this period, government spending on education is financed by bonds sold to the uneducated young. In period 2 (and thereafter), the economy is in the new steady state, with the old educated paying taxes. What happens in the different periods is as follows:

Period 0. The amount of education is $\mathrm{x}$ and $\mathrm{K}$ is the aggregate capital stock (so $\mathrm{k}=\mathrm{K} / \mathrm{x}$ ). The skilled 
wage is $w_{H}(k)$ and the interest rate $r(k)$. The EE locus is: $v(1-x)=x(k+\theta)$. Each uneducated worker consumes $\mathrm{v}(1+\mathrm{r})$ in old age; each old educated worker consumes $\mathrm{c}_{\mathrm{H}}=\mathrm{w}_{\mathrm{H}}(\mathrm{k})-(1+\mathrm{r}) \theta$. Because of credit market imperfections, the level of education in this steady state is less than in the unconstrained equilibrium.

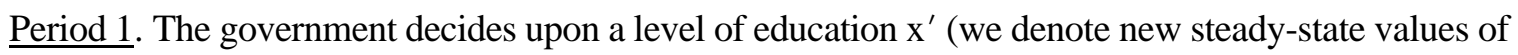
the variables by primes). Suppose $\mathrm{x}^{\prime}>\mathrm{x}$, otherwise it is difficult to see why the government intervenes. It finances the education by selling a quantity of bonds $B$ to the young uneducated. So $B=\theta x^{\prime}$. However, the number of educated workers is that given by the education decision of the previous period (x), and the amount of capital used is that saved in the previous period. Hence the capital stock and number of skilled workers employed in production are unchanged (same as in the old steady state), so the skilled wage and consumption of old skilled workers are also unchanged. The real interest rate is also unaltered, as is the consumption of the unskilled old. The only differences are the change in the number of young uneducated workers (and hence production of the unskilled sector), and the amount of spending on education (both of these reduce resources available for capital accumulation). To determine the amount of capital carried forward to the next period, we use (5) and manipulate, to obtain:

$$
\mathrm{k}^{\prime} \mathrm{x}^{\prime}-\mathrm{kx}=\left(\mathrm{x}-\mathrm{x}^{\prime}\right)(\mathrm{v}+\theta)
$$

That is, capital falls by the sum of (i) the reduction in output of the unskilled sector and (ii) the extra spending on education. So (15) gives us the new steady-state level of capital, as a function of $\mathrm{x}, \mathrm{k}$ and $\mathrm{x}^{\prime}$.

Period 2. Now old skilled workers have no loans, but pay tax, so $\mathrm{c}_{\mathrm{H}}{ }^{\prime}=\mathrm{w}_{\mathrm{H}}{ }^{\prime}\left(1-\tau_{\mathrm{H}}\right)$. The government pays interest on its bonds, so the government budget constraint is

$$
\mathrm{w}_{\mathrm{H}}{ }^{\prime} \tau_{\mathrm{H}} \mathrm{x}^{\prime}=\mathrm{x}^{\prime} \theta\left(1+\mathrm{r}^{\prime}\right)
$$

Using (16), the consumption of the old is the same as in (6):

$$
\begin{gathered}
\mathrm{C}_{\mathrm{H}}{ }^{\prime}=\left[\mathrm{w}_{\mathrm{H}}{ }^{\prime}-\left(1+\mathrm{r}^{\prime}\right) \theta\right] \mathrm{x}^{\prime}, \\
\mathrm{C}_{\mathrm{L}}{ }^{\prime}=\mathrm{v}\left(1-\mathrm{x}^{\prime}\right)\left(1+\mathrm{r}^{\prime}\right),
\end{gathered}
$$

and we have $\mathrm{r}^{\prime}=\mathrm{r}\left(\mathrm{k}^{\prime}\right)$ and $\mathrm{w}_{\mathrm{H}}{ }^{\prime}=\mathrm{w}_{\mathrm{H}}\left(\mathrm{k}^{\prime}\right)$, where $\mathrm{k}^{\prime}$ solves (15). 
The new EE locus is: $\mathrm{v}\left(1-\mathrm{x}^{\prime}\right)=\mathrm{x}^{\prime}\left(\mathrm{k}^{\prime}+\theta\right)$. In the new steady state, since $\mathrm{x}^{\prime}>\mathrm{x}$, and hence, from (15), $\mathrm{k}^{\prime}<\mathrm{k}$, the uneducated are clearly better off (than in the previous steady state), because of the higher interest rate, whereas the educated are worse off (the taxes they pay equal the interest-inclusive cost of education, but the skilled wage is lower and the interest rate higher, because of the fall in $\mathrm{k}$ ). The previously uneducated who were rationed out of education and who now become educated are better off. Note that there is no transitional cost (that is, there is no generation which is worse off as a consequence of the switch from private to public education). Every generation pre-reform receives the old steady-state levels of consumption; the first postreform generation receives the new steady-state levels of consumption.

To maximize social welfare, we need to choose $\mathrm{x}^{\prime}$ so as to maximize (14), subject to the relevant constraints, which are the expressions for consumption, (17), and the relationship between $\mathrm{k}^{\prime}$ and $\mathrm{x}^{\prime}$, as embodied in (15) (equation (17a) already incorporates the government budget constraint). The maximand is: $\Omega\left(\mathrm{x}^{\prime}\right)=\mathrm{C}_{\mathrm{H}}\left(\mathrm{x}^{\prime}\right)+\mathrm{C}_{\mathrm{L}}\left(\mathrm{x}^{\prime}\right)-\epsilon \mathrm{x}^{\prime}\left(\mathrm{x}^{\prime}-1\right)$. We substitute (17) into this expression and maximize with respect to $\mathrm{x}^{\prime}$, taking into account the effects on the expression of changes in $\mathrm{k}^{\prime}$ due to changes in $\mathrm{x}^{\prime}$ according to (15). However, the effects of changes in $\mathrm{k}^{\prime}$ on social welfare vanish, and after some manipulation we obtain:

$$
\mathrm{w}_{\mathrm{H}}{ }^{\prime}-(1+\mathrm{r})(\mathrm{v}+\theta)-\epsilon\left(2 \mathrm{x}^{\prime}-1\right)=0 .
$$

This is exactly the equation for the SS locus (equation (8)). The EE locus is also the same as in the unconstrained equilibrium and the welfare maximum is the unconstrained equilibrium; so, it might seem, not only can government provision of education financed by taxing the educated restore the unconstrained equilibrium but it is optimal for it to do so.

However, there is an objection to this conclusion. Suppose the reason the economy with private education cannot obtain the unconstrained equilibrium is a credit constraint. Let us suppose that the alternative explanation of credit constraints holds - that is, if the borrower fails to repay the loan, he incurs a penalty of $\pi$. This constrains the loan (denoted $\mathrm{L}$ ) to be such that $(1+\mathrm{r}) \mathrm{L} \leq \pi$, giving rise to the credit constraint. Suppose also that if the taxpayer fails to pay his taxes, then he incurs the same penalty, of $\pi$. It is apparent, 
then, that in this case the government is constrained in exactly the same way as the private sector, and hence cannot support the level of education in the unconstrained equilibrium by taxing the beneficiaries.

\subsection{Public Education Financed by Taxing the Uneducated}

Clearly, the government can finance spending in ways other than taxing its (direct) beneficiaries. To illustrate, we consider that public education is introduced in Period 1, financed by a tax on the young uneducated. Hence $\tau_{\mathrm{L}} \mathrm{v}=\theta \mathrm{x}^{\prime} /\left(1-\mathrm{x}^{\prime}\right)$. Consumption of the old in this period is the same as in the previous steady state. However, the government does not need to borrow now and equation (15) is unaltered. In Period 2 (and subsequently), the economy is in its new steady state. Because it is the uneducated who have been taxed, consumption of the two groups is given now by

$$
\begin{gathered}
\mathrm{C}_{\mathrm{H}}{ }^{\prime}=\mathrm{w}_{\mathrm{H}}{ }^{\prime} \mathrm{x}^{\prime}, \\
\mathrm{C}_{\mathrm{L}}{ }^{\prime}=\mathrm{v}\left(1-\tau_{\mathrm{L}}\right)\left(1+\mathrm{r}^{\prime}\right)\left(1-\mathrm{x}^{\prime}\right)=\left[\mathrm{v}\left(1-\mathrm{x}^{\prime}\right)-\theta \mathrm{x}^{\prime}\right]\left(1+\mathrm{r}^{\prime}\right) .
\end{gathered}
$$

Substituting (19) into $\Omega\left(\mathrm{x}^{\prime}\right)$, and differentiating, we obtain the following condition for maximization:

$$
\mathrm{w}_{\mathrm{H}}{ }^{\prime}-(\mathrm{v}+\theta)\left(1+\mathrm{r}^{\prime}\right)-\epsilon\left(2 \mathrm{x}^{\prime}-1\right)=0 \text {. }
$$

This is, again, the equation of the SS curve. Since the same equation as before holds for the EE curve, we conclude that the optimal policy for the government is to restore the unconstrained equilibrium levels of $\mathrm{x}$ and k. (It may be noted that this does not now restore the unconstrained equilibrium levels of consumption of the two groups.) This gives the same value of the SWF as in the unconstrained equilibrium, so it would seem that it does not matter how the government finances its expenditures, provided it manages to get the economy to the unconstrained equilibrium again.

However, if the public provision of education is financed this way, educated workers will be better off (since they pay no tax and repay no education loan) and uneducated workers worse off (since they now are taxed) than in the unconstrained equilibrium. There are hence uneducated workers who would have really liked to have acquired education, but are prevented from doing so - the government rations education. In a sense, there is an externality from becoming educated if education is financed by taxing the uneducated. Someone who 
becomes educated thereby avoids paying taxes, but this means that the taxes he would have paid (and the cost of his own education) are now paid by other uneducated tax payers. Optimality hence requires the government to ration education.

So far we have assumed that the government can ensure that the uneducated pay their taxes and are not subject to the type of constraint they face when taxing the educated (or, if they do, it is not binding at the optimum). It might be that this constraint does not bind when the optimal level of education is financed by taxing the uneducated - the uneducated may be less able to evade taxes because they may be less mobile, or may not be able to hire sophisticated accountants. However, even if such a constraint binds and prevents the attainment of the optimum, then the government should be able to improve on the constrained equilibrium by taxing both the educated and uneducated. It is possible to replicate the constrained equilibrium by taxing the educated and then to improve on this by raising education further, now financing it by taxing the uneducated. Provided the ICC does not prevent at least some revenue being raised from the uneducated, it is therefore possible for government policy to improve on the constrained equilibrium.

A number of studies have established that "the net effect of public support for higher education is a transfer of resources from lower-income to higher-income individuals" (Fernandez and Rogerson, 1995, p. 250). Our model can explain this observation - if the rationale for public support is that a credit constraint prevents the private sector from allocating education efficiently, the same ICC that generates the credit constraint makes it impossible for the government to finance its expenditure by taxing just the beneficiaries. (Note that this argument requires us to identify the unskilled with low-income individuals and the skilled with high-income individuals, which seems reasonable.) Fernandez and Rogerson explain the phenomenon with a political economy mechanism; we would regard our explanation as complementary with theirs.

\subsection{A Public Subsidy to Education}

It might be asked why government intervention should take the form of government provision of education and whether the mere subsidy of education would not be sufficient to solve the problem. Accordingly, 
consider that instead of providing education itself, the government provides a subsidy of s to everyone who purchases education, so that the net price of education paid by the purchaser falls to $\theta$ - s. As before, we need to specify how the subsidy is financed and, again, consider two possibilities, financing the spending by taxing the educated and uneducated respectively. The analysis parallels that of the previous subsections - in the case of the subsidy financed by taxing the educated, we suppose that when the subsidy is first introduced, it is financed by the sale of bonds to the uneducated, and every subsequent old educated generation is taxed to finance both the current subsidy and interest on the debt. We can show that, providing the government has no difficulty taxing the educated, it should be able to replicate the unconstrained equilibrium and this is optimal. However, this result is subject to the same criticism as is our earlier result that public education financed by taxing the educated can restore the unconstrained equilibrium. If borrowers can abscond without paying the tax, there is exactly the same ICC which prevented the private sector from attaining the unconstrained equilibrium, so a subsidy financed by a tax on the educated cannot improve matters.

We are hence led to consider an education subsidy financed by a tax on the uneducated and, again, as before we can show that the government can re-establish the unconstrained equilibrium values of $\mathrm{x}$ and $\mathrm{k}$ (and this is optimal). The utilities of agents will differ from their levels in the unconstrained equilibrium, as the educated now pay no tax, although they repay the loan taken out to finance the subsidized cost of education, and the uneducated now pay tax. There is still rationing of education, but it is rationing enforced by the lender, not by the government. Indeed, it is possible to give conditions under which policy will be Pareto improving:

Condition P: (Pareto Improvement) (i) $\pi>\theta-\mathrm{v}$ and (ii) $\mathrm{v}\left(\Psi^{\mathrm{u}}\right)^{-1}(0)>\theta\left(\Psi^{\mathrm{c}}\right)^{-1}(0)$.

Notice that the conditions are sufficient, but not necessary. (For example, one may have Part (i) violated, i.e., $\pi \leq \theta-\mathrm{v}$, but the associated condition in Part (ii) would become very clumsy.) Obviously, Part (i) requires the unskilled wage and the absconding cost not to be too low. For values of $\pi, \theta$ and v satisfying Part (i) of both Conditions $\mathrm{C}$ and $\mathrm{P}$, Part (ii) is met if $\pi$ and $\theta-\mathrm{v}$ are sufficiently small (compared to the equilibrium skilled 
wage) or if $\epsilon$ is sufficiently large. ${ }^{19}$ That is, in an economy with sufficiently large ex ante heterogeneity $(\epsilon)$ or ex post heterogeneity (in equilibrium wages), the equilibrium real interest rate differential between the unconstrained and constrained economies will be high and Condition P will hold. Accordingly, we have:

Proposition 4: (Education Subsidy) In the presence of credit market imperfections, a Pigovian subsidy to education of $\mathrm{s}=(\theta-\mathrm{v})-\pi /(1+\mathrm{r})$ financed solely by a tax on the young unskilled can restore the unconstrained equilibrium and this is optimal. Under Condition P, the subsidy leads to a Pareto improvement over the constrained equilibrium.

Call the equilibrium with optimal government subsidy the subsidy equilibrium. There are three types of agent to consider. Those who are educated in both the constrained and subsidy equilibria are better off because of the subsidy, worse off because of a lower real wage and higher real interest rate. However, it turns out that they are always better off at the subsidy equilibrium as the net benefits exceed the net costs. Those uneducated in the constrained equilibrium but educated in the subsidy equilibrium are better off than they would have been had they stayed uneducated. Those who are uneducated in both equilibria are worse off because of the tax they pay, better off because of the higher real interest rate they receive. Our Proposition identifies conditions under which all agents will be better off. (It may be noted that under public education financed by taxing the uneducated, those who are uneducated under both private and public provision are always worse off; hence, public provision of education in this financing scheme is not Pareto improving.)

So, if the government cannot finance a subsidy to education which restores the unconstrained equilibrium by taxing the educated, it may be possible to do so by taxing the uneducated; this can achieve the same level of social welfare as in the unconstrained equilibrium. It might seem, then, that there is no reason for the government to provide education - a subsidy to education should suffice. However, we now propose to show that this equivalence does not always hold. 


\subsection{Government Provision and Government Subsidy Compared}

To show that government provision may be preferable to government subsidy, we need to modify the above framework. A simple way of so doing is to suppose that workers differ in their costs of default ( $\pi$ ), and the different values of these costs can be observed costlessly by lenders. Specifically, let us suppose there is a $50 \%$ chance that any potential borrower has a cost of default so low that, for the range of parameter values under consideration, he will always default. Alternatively, the borrower has the value of $\pi$ assumed in the paper. If the government provides education, and provides it efficiently, it will provide it to all agents with $\alpha$ less than or equal to $\epsilon(2 \mathrm{x}-1)$. Alternatively, suppose the same level of education is offered by the private sector subsidized by the government. Then because of the possibility of default, those educated will be those agents with $\alpha$ less than or equal to $2 \epsilon(2 x-1)$ who are not going to default. Then the total disutility of education of those who are educated under government provision is $\mathrm{D}_{\mathrm{G}} \equiv \epsilon(\mathrm{x}-1) \mathrm{x}$; the total disutility of education of those who are educated under private provision with a government subsidy is $D_{S} \equiv \epsilon(2 x-1) x$. The difference in social welfare, then, between state-provided and state-subsidized education of $\mathrm{x}$ is hence $-\left(\mathrm{D}_{\mathrm{S}}-\mathrm{D}_{\mathrm{G}}\right)=\epsilon \mathrm{x}^{2}$ $>0$. The other terms in the social welfare function are exactly the same: the first two components of (20) are the same in both cases. So here we have a case where government provision of education strictly dominates government subsidy.

The idea is that the government chooses those with the lowest disutility cost of education to be educated; the private sector chooses those with the greatest likelihood of repaying. The example is fairly special but the underlying idea seems fairly sensible. The government can do its best to ensure that those for whom the net benefit to society of their being educated are educated. The private sector will instead choose those who are most likely to repay loans (or at least those who are able to obtain finance). One can think of able but poor students not obtaining education while rich but less able students are educated. Our analysis points to a possibility that the government may be able to ensure that education is more efficiently allocated among the populace than the private sector. 


\section{CONCLUSION}

This paper has presented an overlapping-generations model with educational choice where lenders cannot ensure that money lent is repaid. This gives rise to the possibility of endogenous credit constraints, and certain mutually beneficial transactions do not take place. In general, it seems that credit constraints reduce the amount of human capital accumulation and raise physical capital accumulation. The skilled wage rises and the interest rate falls. Inequality between the skilled and unskilled rises.

We have also explored the effects of public policy designed to remedy the problem. We have identified several ways in which it may be possible for the government to improve on the private sector if credit market imperfections are the reason why private sector provision is inefficient. The first, that the government may be superior to the private sector in contract enforcement, is one we are fairly skeptical about; we see no reason why this should be so. The second is that the government may be able to finance its spending by taxing those who are not (direct) beneficiaries, and this may be desirable according to some social welfare functions. It may even be Pareto improving. The third is the government's ability to choose who is, and who is not, educated, may give rise to a better allocation of education amongst agents.

Of possible extensions to our analysis, we would mention two. First, one might extend the model to allow for endogenous growth in a way similar to Glomm and Ravikumar (1992) and Lloyd-Ellis (2000) so as to study issues relating to growth and inequality. Second, we have ignored political economy considerations, assuming instead that the government acts as a benevolent social welfare maximizer. We believe this is defensible in identifying reasons why government intervention might, at least in principle, be beneficial. However, there are agents who might be harmed by a change which raises social welfare; for example, those who can borrow in the credit constrained regime are worse off in the unconstrained regime even though the latter is preferable according to our social welfare function. If such a group is politically powerful, this might be another reason why education might be financed by taxing nonbeneficiaries, but a more thorough analysis of these issues would surely be desirable. 


\section{APPENDIX}

Proof of Proposition 1: First, recall that the CC locus cuts the SS locus from below. By utilizing Figure 2 to compare the unconstrained (point E) and constrained (point C) equilibria, the results of lower $\mathrm{x}$ and higher $\mathrm{k}$ (and hence higher $\mathrm{w}_{\mathrm{H}}$ and lower $\mathrm{r}$ ) follow immediately. In the absence of market imperfections or distortions, the proof of the property that the unconstrained equilibrium is Pareto efficient is standard. The Pareto inefficiency of the unconstrained equilibrium is trivial. Consider the marginal worker rationed out of education, and suppose the ICC is relaxed so that he becomes educated. Then he is better off, and since the same amount of output is produced in the rest of the economy, lump-sum transfers and taxes can ensure no-one is worse off. Yet, the constrained equilibrium is not Pareto comparable to the unconstrained equilibrium, because those remaining skilled are better-off whereas those remaining unskilled are worse-off under credit constraints.

Proof of Proposition 3: Totally differentiating (13) and (9), we obtain:

$$
\left[\begin{array}{cc}
-2 \epsilon & a_{12} \\
a_{21} & -x
\end{array}\right]\left[\begin{array}{l}
d x \\
d k
\end{array}\right]=\left[\begin{array}{cccc}
2 x-1 & 0 & 2(1+r) & -1 \\
0 & (x-1) & x & 0
\end{array}\right]\left[\begin{array}{c}
d \epsilon \\
d v \\
d \theta \\
d \pi
\end{array}\right],
$$

where $\mathrm{a}_{12}=\beta(\mathrm{r}+\delta)(2 \theta / \mathrm{k}+1)$ and $\mathrm{a}_{21}=-(\theta+\mathrm{v}+\mathrm{k})$. We define the determinant of the pre-multiplying matrix as $\mathrm{M} \equiv 2 \mathrm{x} \epsilon-\mathrm{a}_{12} \mathrm{a}_{21} \equiv 2 \mathrm{x} \epsilon+(\mathrm{k}+\theta+\mathrm{v})(\mathrm{k}+2 \theta)(\mathrm{r}+\delta) \beta / \mathrm{k}>0$. Applying Cramer's rule yields:

$$
\begin{aligned}
& \mathrm{dx} / \mathrm{d} \epsilon=(1-2 \mathrm{x}) \mathrm{x} / \mathrm{M} \quad>0 \quad \text { (since } \mathrm{x}<1 / 2 \text { under Condition } \mathrm{E}) \\
& \mathrm{dk} / \mathrm{d} \epsilon=-(1-2 \mathrm{x})(\mathrm{k}+\theta+\mathrm{v}) / \mathrm{M} \quad<0 \\
& \mathrm{dx} / \mathrm{dv}=(1-\mathrm{x}) \beta(\mathrm{r}+\delta)(2 \theta+\mathrm{k}) /(\mathrm{kM}) \quad>0 \\
& \mathrm{dk} / \mathrm{dv}=2 \epsilon(1-\mathrm{x}) / \mathrm{M} \quad>0 \\
& \mathrm{dx} / \mathrm{d} \theta=-\mathrm{x}[\beta(\mathrm{r}+\delta)(2 \theta+\mathrm{k}) / \mathrm{k}+2(1+\mathrm{r})] / \mathrm{M}<0 \\
& \mathrm{dk} / \mathrm{d} \theta=2[(\mathrm{k}+\theta+\mathrm{v})(1+\mathrm{r})-\epsilon \mathrm{x}] / \mathrm{M} \\
& \mathrm{dx} / \mathrm{d} \pi=\mathrm{x} / \mathrm{M} \quad>0 \\
& \mathrm{dk} / \mathrm{d} \pi=-(\mathrm{k}+\theta+\mathrm{v}) / \mathrm{M} \quad<0 .
\end{aligned}
$$

Proof of Theorem 2': From (7) and (9), the unconstrained equilibrium capital-labor ratio $\mathrm{k}^{\mathrm{U}}$ solves:

$$
\begin{aligned}
\Phi(\mathrm{k}) & \equiv\left\{\beta \mathrm{k}^{1-\beta}-(\theta+\mathrm{v})\left[1+(1-\beta) \mathrm{k}^{-\beta}-\delta\right]\right\}(\theta+\mathrm{v}+\mathrm{k})+\epsilon(\theta-\mathrm{v}+\mathrm{k}) \\
& =\left\{\beta \mathrm{k}^{1-\beta}-(\theta+\mathrm{v})\left[1+(1-\beta) \mathrm{k}^{-\beta}-\delta\right]+\epsilon\right\}(\theta+\mathrm{v}+\mathrm{k})-2 \epsilon \mathrm{v}=0,
\end{aligned}
$$

where $\Phi$ is locally increasing in $\mathrm{k}$ because (7) implies $\beta \mathrm{k}^{1-\beta}-(\theta+\mathrm{v})\left[1+(1-\beta) \mathrm{k}^{-\beta}-\delta\right]+\epsilon=2 \epsilon \mathrm{x}>0$ at k=k . 
In order for an NCCSSE to exist, we must thus have $\mathrm{k}^{\mathrm{U}}<\mathrm{k}_{\mathrm{IC}}<\mathrm{k}_{\max }$, where $\mathrm{k}_{\mathrm{IC}}=[(1-\beta) /(\pi / \theta-1+\delta)]^{1 / \beta}$ and $\mathrm{k}_{\max } \equiv[(1-\beta) / \delta]^{1 / \beta}$. Obviously, the second inequality is equivalent to $\pi>\theta$. We next turn to establishing a sufficient condition to ensure the first inequality. Utilizing the locally monotone increasing property of $\Phi$, we have $\mathrm{k}^{\mathrm{U}}<\mathrm{k}_{\mathrm{IC}}$ if $\Phi\left(\mathrm{k}_{\mathrm{IC}}\right)>0$. Since $1+(1-\beta)\left(\mathrm{k}_{\mathrm{IC}}\right)^{-\beta}-\delta=\pi / \theta, \theta>\mathrm{v}$ and $\mathrm{k}>0$, it is sufficient for $\Phi\left(\mathrm{k}_{\mathrm{IC}}\right)>0$ if $\beta\left(\mathrm{k}_{\mathrm{IC}}\right)^{1-\beta}>\pi / \theta$. Finally, the uniqueness property is trivial as the EE locus is downward sloping while the $\mathrm{CC}^{\prime}$ locus is vertical.

Proof of Proposition 4: The first part of the Proposition concerning the possibility of either type of education subsidies to restore the unconstrained equilibrium has been proved in the text. We therefore focus on the second part: a subsidy of education by taxing the unskilled may generate Pareto improvement under Condition P. To perform Pareto ranking, we distinguish three types of agents: (i) (type-H) originally skilled under credit constraints and still skilled with subsidy; (ii) (type-M) originally unskilled under credit constraints and skilled with subsidy; and (iii) (type-L) originally unskilled under credit constraints and still unskilled with subsidy. Since type-M agents are better off than type-L agents in the new equilibrium (by the revealed preference argument) but equally well off in the old equilibrium, it is suffices to establish the result by showing that both type-H and type-L agents are better off in the new equilibrium. In the constrained equilibrium with a subsidy at $\mathrm{s}=(\theta-\mathrm{v})-\pi /(1+\mathrm{r})$, both $\mathrm{x}$ and $\mathrm{k}$ are restored to the unconstrained values, as do $\mathrm{w}_{\mathrm{H}}$ and $\mathrm{r}$, thus implying,

$$
\mathrm{c}_{\mathrm{H}}=\mathrm{w}_{\mathrm{H}}-(1+\mathrm{r})(\theta-\mathrm{s}) ; \quad \mathrm{c}_{\mathrm{L}}=\mathrm{v}\left(1-\tau_{\mathrm{L}}\right)(1+\mathrm{r}) \text {. }
$$

In the constrained equilibrium without education subsidy, we have:

$$
\mathrm{c}_{\mathrm{H}}{ }^{\mathrm{P}}=\mathrm{w}_{\mathrm{H}}{ }^{\mathrm{P}}-\left(1+\mathrm{r}^{\mathrm{P}}\right) \theta ; \quad \mathrm{c}_{\mathrm{L}}{ }^{\mathrm{P}}=\mathrm{v}\left(1+\mathrm{r}^{\mathrm{P}}\right) .
$$

where the superscript ' $\mathrm{P}$ ' is use to denote pre-subsidy variables under credit constraints. Recall from Proposition 1 that $\mathrm{x}-\mathrm{x}^{\mathrm{P}}>0$ and $\mathrm{r}-\mathrm{r}^{\mathrm{P}}>0$. Define $\Delta_{\mathrm{i}}$ as the net utility change of a type-i agent from a constrained equilibrium without subsidy to that restoring the unconstrained level of (x, k) with a subsidy s. Using the SS locus (8) and the CC locus (11) to substitute out $\mathrm{w}_{\mathrm{H}}$ and $\mathrm{w}_{\mathrm{H}}{ }^{\mathrm{P}}$, respectively, and applying (12a) and (12b), the expression for $s$ and the government budget constraint $s x=\tau_{L} v(1-x)$, we obtain:

$$
\begin{array}{rlrl}
\Delta_{\mathrm{H}}=\mathrm{c}_{\mathrm{H}}-\mathrm{c}_{\mathrm{H}}^{\mathrm{P}} & =2 \epsilon\left(\mathrm{x}-\mathrm{x}^{\mathrm{P}}\right)+\theta\left(\mathrm{r}-\mathrm{r}^{\mathrm{P}}\right)>0 ; & \\
\Delta_{\mathrm{L}}=\mathrm{c}_{\mathrm{L}}-\mathrm{c}_{\mathrm{L}}^{\mathrm{P}} & =\mathrm{v}\left(\mathrm{r}-\mathrm{r}^{\mathrm{P}}\right)-[(\theta-\mathrm{v})(1+\mathrm{r})-\pi][\mathrm{x} /(1-\mathrm{x})] & \\
& >\mathrm{v}\left(\mathrm{r}-\mathrm{r}^{\mathrm{P}}\right)-(\theta-\mathrm{v}) \mathrm{r}[\mathrm{x} /(1-\mathrm{x})] & & (\text { since } \pi>\theta-\mathrm{v} \text { under Condition } \mathrm{P}(\mathrm{i})) \\
& >\mathrm{v}\left(\mathrm{r}-\mathrm{r}^{\mathrm{P}}\right)-(\theta-\mathrm{v}) \mathrm{r}(\mathrm{v} / \theta) & & \left(\text { since } \mathrm{x} /(1-\mathrm{x})<\mathrm{x}_{\max } /\left(1-\mathrm{x}_{\max }\right)=\mathrm{v} / \theta\right) \\
& =(\mathrm{v} / \theta)\left\{\mathrm{v}\left(\Psi^{\mathrm{u}}\right)^{-1}(0)-\theta\left(\Psi^{\mathrm{c}}\right)^{-1}(0)\right) &
\end{array}
$$

which is positive under Condition $\mathrm{P}(\mathrm{ii})$. Thus, an education subsidy of s leads to a Pareto improvement. 


\section{REFERENCES}

Aghion, P. and Bolton, P., "A Theory of Trickle-Down Growth and Development," Review of Economic Studies 64 (1997), 151 - 172.

Azariadis, C. and Smith, B., "Adverse Selection in the Overlapping Generations Model: The Case of Pure Exchange," Journal of Economic Theory 60 (1993), 277 - 305.

Banerjee, A. and Newman, A., "Occupational Choice and the Process of Development," Journal of Political Economy 101 (1993), 274 - 298.

Barham, V., Boadway, R., Marchand, M. and Pestieau, P., "Education and the Poverty Trap," European Economic Review 39 (1995), 1257 - 1275.

Barro, R.J., "Human Capital and Growth," American Economic Review, Papers and Proceedings 91 (2001), $12-17$.

Bergström, V. and Panas, E., "How Robust is the Capital-Skill Complementarity Hypothesis?" Review of Economics and Statistics 74 (1992), 540 - 546.

De Gregorio, J., "Borrowing Constraints, Human Capital Accumulation, and Growth,” Journal of Monetary Economics 37 (1996), 49 - 71.

Eicher, T., "Interaction between Endogenous Human Capital and Technical Change," Review of Economic Studies 63 (1996), 127 - 144.

Evans, D. and Jovanovic, B., “An Estimated Model of Entrepreneurial Choice under Liquidity Constraints,” Journal of Political Economy 97 (1989), 808 - 827.

Fender, J., “A Simple Macroeconomic Model with Endogenous Credit Rationing," Annales d'Économie et de Statistique $37 / 38$ (1995), 215 - 36.

Fernandez, R. and Rogerson, R., "On the Political Economy of Education Subsidies," Review of Economic Studies 62 (1995), 249 - 62.

Galor, O. and Zeira, J., “Income Distribution and Macroeconomics,” Review of Economic Studies 60 (1993), $35-53$.

Glomm, G. and Ravikumar, B., "Public versus Private Investment in Human Capital: Endogenous Growth and Income Inequality,” Journal of Political Economy 100 (1992), 818 - 834. 
Hanushek, E. and Kimko, D., "Schooling, Labor-Force Quality and the Growth of Nations,"American Economic Review 90 (2000), 1184 - 1208.

Hare, P. and Ulph, D., "Imperfect Capital Markets and the Public Provision of Education," Public Choice 36 (1981), $481-507$.

Hart, O. and Moore, J., “A Theory of Debt Based on the Inalienability of Human Capital," Quarterly Journal of Economics 109 (1994), 841 - 79.

Jacoby, H. and Skoufias, E., "Risk, Financial Markets, and Human Capital in a Developing Country," Review of Economic Studies 64 (1997), 311 - 335.

Japelli, T. and Pagano, M., "Savings, Growth and Liquidity Constraints," Quarterly Journal of Economics 109 (1994), 83 - 110.

Kehoe, T. and Levine, D., "Debt-Constrained Asset Markets," Review of Economic Studies 60 (1993), 865 888.

Laing, D., Palivos, T. and Wang, P., "Learning, Matching and Growth," Review of Economic Studies 62 (1995), $115-129$.

Lazear, E., "Family Background and Optimal Schooling Decisions," Review of Economics and Statistics 62 (1980), $42-51$.

Lloyd-Ellis, H., "Public Education, Occupational Choice, and the Growth-Inequality Relationship," International Economic Review 41 (2000), 171 - 201.

Sappington, D., "Limited Liability Contracts between Principal and Agent," Journal of Economic Theory 29 (1983), $1-23$.

Tsiddon, D., “A Moral Hazard Trap to Growth,” International Economic Review 33 (1992), 299 - 321.

Wang, P., "Money, Competitive Efficiency and Intergenerational Transactions," Journal of Monetary Economics 32 (1993), 303 - 320.

Zeira, J., "Credit Rationing in an Open Economy," International Economic Review 32 (1991), 959 - 972. 


\section{ENDNOTES}

1. A version of the paper was completed while the first author was visiting Chinese University of Hong Kong and the second author CentER (Tilburg), Rochester and Washington-Seattle. Early drafts were presented in seminars at these and the authors' own institutions, as well as at Edinburgh, Kobe, Osaka, the Social and Economic Research Institute (Japan), the European Economic Association Meetings, the Midwest Macroeconomic Conference, the NBER Summer Institute, the Public Economics Working Group, and the Royal Economic Society Conference. We would like to thank participants, and especially Tim Besley, Eric Bond, Spiros Bougheas, Theo Eicher, James Foster, Derek Laing, Kazuo Mino, Ted Palivos, Rob Reed, Mark

Roberts, Richard Rogerson, Robert Shimer, Koji Shimomura, Peter Sinclair, Alan Stockman, Thijs ten Raa, David Wildasin and an anonymous referee for helpful comments and suggestions. Financial support from the University of Birmingham is acknowledged. The usual disclaimer applies.

2. See, for example, Hanushek and Kimko (2000), Barro (2001) and many papers cited therein.

3. There is also evidence on the importance of credit constraints on lending to entrepreneurs (Evans and Jovanovic 1989) and to households (Japelli and Pagano 1994).

4. Other related papers are Hare and Ulph (1981), Glomm and Ravikumar (1992), Azariadis and Smith (1993), Barham, Boadway, Marchand and Pestieau (1995), Laing, Palivos and Wang (1995), De Gregorio (1996), Eicher (1996) and Lloyd-Ellis (2000). Glomm and Ravikumar, Laing et al., Eicher and Lloyd-Ellis, among many others, model education in a dynamic general-equilibrium framework without credit market imperfections. Azariadis and Smith model credit constraints in a pure exchange economy. Both Hare and Ulph and Barham et al. study educational choice and imperfect capital markets, assuming exogenous credit constraints and interest rates. De Gregorio incorporates exogenous borrowing constraints in a growth model with human capital accumulation. None of these papers permits an endogenous choice between borrowing and lending, which plays an important role in generating some of our main results, and there is no comparable discussion of the public policy implications of credit constraints. 
5. Aghion and Bolton (1997) have endogenous choice between becoming a borrower or lender in a model where agents differ in initial wealth and physical investment loans are subject to credit constraints. They consider primarily the trickle-down effect of physical capital accumulation when credit constraints underpin persistent income inequalities.

6. Since credit constraints are endogenous, our discussion of "the consequences of credit constraints" might be objected to. We have a parameter which measures the costs of default, and when we discuss "the consequences of credit constraints," what we really mean are "the consequences of reducing the costs of default parameter."

7. We have explored a number of alternative assumptions, such as three-period lived agents to allow the skilled to save in the middle age, the unskilled to work in both periods, and agents who consume in both periods to add an additional channel of savings than that via endogenous occupational choice, but found that while such setups complicate the analysis, they do not change the essential conclusions.

8. Lloyd-Ellis (2000, p. 175) considers a variable capturing "the effort exerted in acquiring higher education," which, although endogenous, can be given an interpretation similar to our disutility/innate ability parameter, $\alpha$.

9. We sometimes contrast the results of this benchmark model with an alternative which assumes that the marginal product of skilled labor is constant and it is unskilled labor which combines with capital in a CobbDouglas technology. While this alternative model may not be realistic, it allows us to check the robustness of our results. The general case, where capital combines with both types of labor in a CES function is much more complex; we have analyzed the case where skilled and unskilled labor are perfect substitutes (where one unit of skilled labor substitutes for several units of unskilled) and the relevant labor aggregate combines with capital to produce output. The results are virtually identical with those of the benchmark model. (Results for these versions of our model are available on request.)

10. The assumption of $\theta>\mathrm{v}$ is sufficient but not necessary. It is imposed to simplify the analysis. It implies that, in steady-state equilibrium, the fraction of the population educated must be less than half 
(otherwise, there will be insufficient funds to support education expenditure); this further simplifies the comparative static results. Also, it is worth noting that in order for credit constraints to emerge (see Section 4 below), this assumption is required; it can be weakened if we allow the unskilled and defaulters (who borrow but do not invest in education) to earn in the second period of their lives.

11. There are, of course, adverse selection arguments for credit constraints, as well, which we do not adopt here, because of their greater analytical complexity.

12. The account developed here is based on Fender (1995). Related moral hazard explanations of credit constraints are found in Banerjee and Newman (1993) and Kehoe and Levine (1993), as well as in Zeira (1991), Tsiddon (1992) and Galor and Zeira (1993).

13. Such costs therefore capture the spirit of Kehoe and Levine (1993) in which "creditors can seize the assets of debtors who default on their debts" (p. 869).

14. If lenders cannot observe $\alpha$, then we would expect them to lend to everyone who requests a loan, but to charge a risk-related interest rate which ensures that they, on average, just break even. If there is no interest rate at which this happens, then there is no lending - a rather extreme case of credit constraints.

15. Part (ii) of Condition $\mathrm{C}$ is sufficient but not necessary. The necessary and sufficient condition is: $\beta\left(\mathrm{k}_{\max }\right)^{1-\beta}+\pi+\epsilon\left(\theta-\mathrm{v}+\beta \mathrm{k}_{\max }\right) /\left(\theta+\mathrm{v}+\beta \mathrm{k}_{\max }\right)>2 \theta$.

16. In the case where capital and unskilled labor are complementary, the marginal product of capital effect tends to raise the rate of real interest. However, the negative effect of credit constraints on the real interest rate remains as long as its effect on the unskilled wage dominates that on the marginal product of capital.

17. This is calculated as follows: the average disutility of education is $\left(-\epsilon+\alpha^{*}\right) / 2$; multiplying this by $\mathrm{x}$ and using the steady-state version of (4) gives the last term on the right-hand side of (14).

18. For a more technical discussion of social welfare maximization see Wang (1993).

19. To see this, notice that under Condition $\mathrm{E}, \Psi^{\mathrm{c}}(\mathrm{r})$ is steeper than $\Psi^{\mathrm{u}}(\mathrm{r})$ (both are downward-sloping) and $\epsilon$ shifts $\Psi^{\mathrm{c}}(\mathrm{r})$ outwards by more than $\Psi^{\mathrm{u}}(\mathrm{r})$. 
Figure 1: Sequence of Actions in the Basic Framework

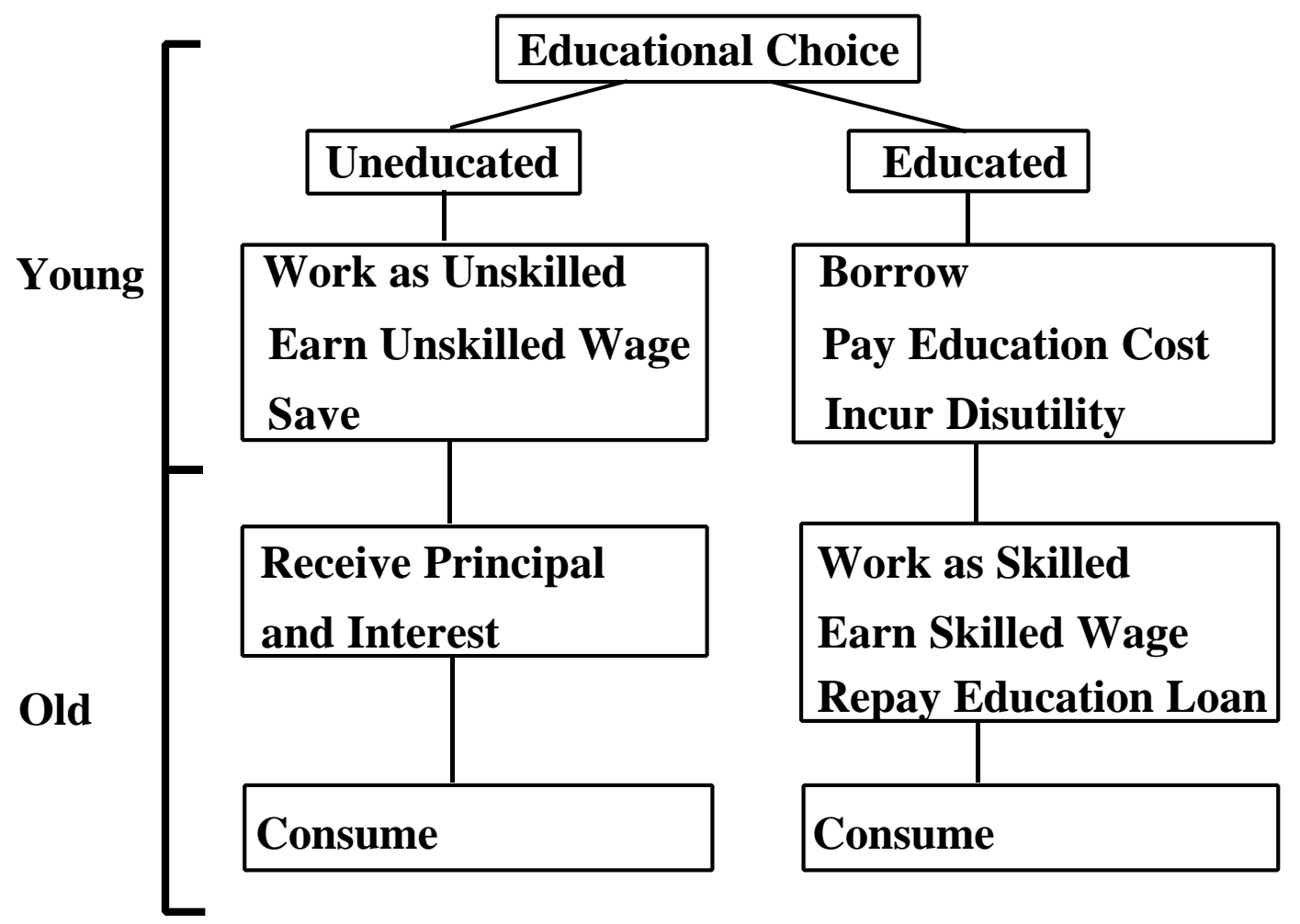


Figure 2: Nondegenerate Steady-State Equilibrium in the Absence of Credit Constraints

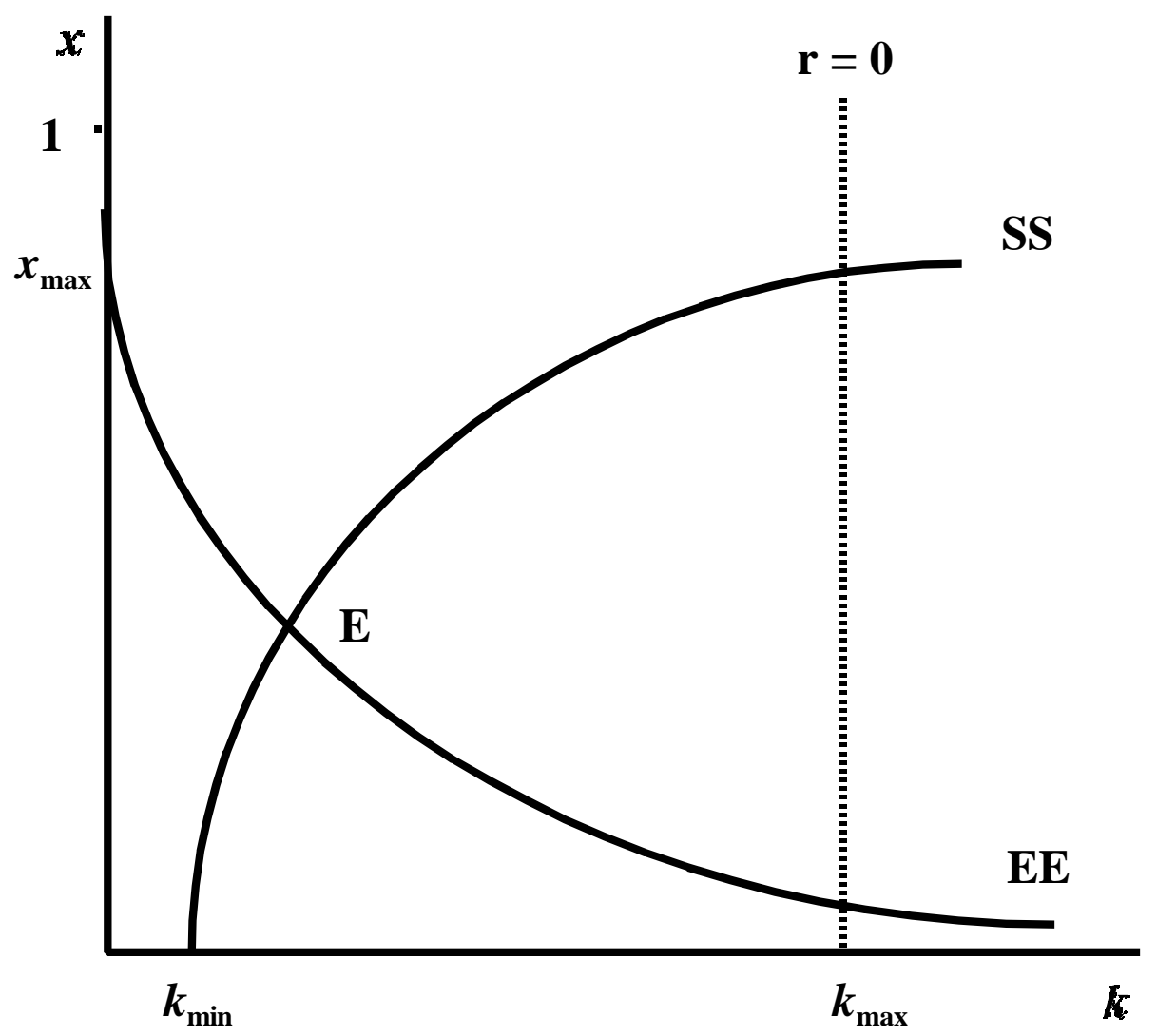


Figure 3: Nondegenerate Steady-State Equilibrium in the Presence of Credit Constraints

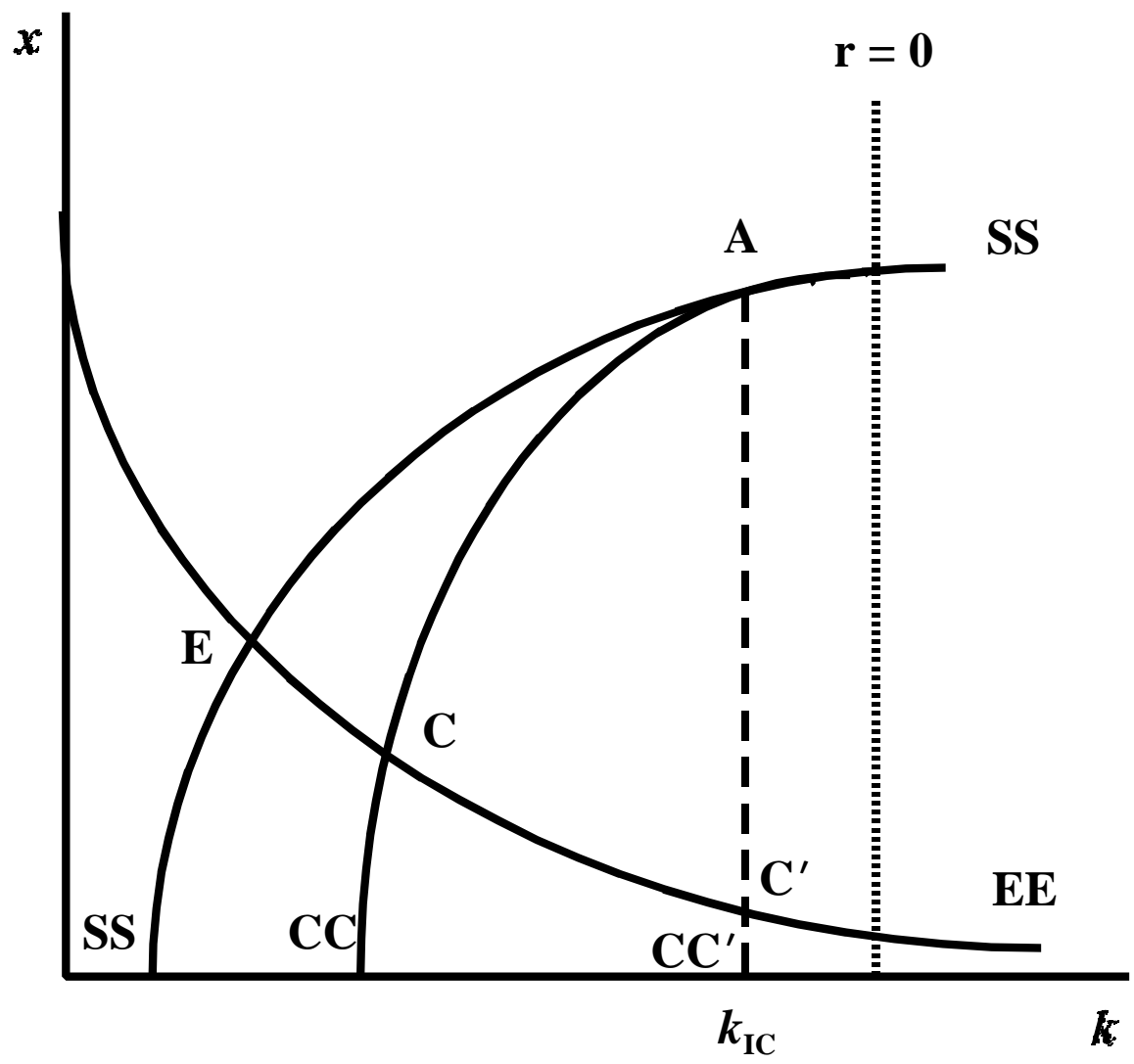




\section{Appendix for the Referee (Not Intended for Publication)}

This appendix provides a Figure that illustrates the comparison between the unconstrained and constrained equilibria in terms of $\mathrm{r}$, which also helps to understand the primitives required for Condition $\mathrm{P}$ to be met. In particular, Condition E implies that $2(1+r) \theta-\pi$ is always steeper than $(1+r)(\theta+v)$ and hence $\Psi^{\mathrm{c}}(\mathrm{r})$ is always steeper than $\Psi^{\mathrm{u}}(\mathrm{r})$. Since an increase in $\epsilon$ shifts $\Psi(r)$ outward at which the $2(1+r) \theta$ $\pi$ and $(1+r)(\theta+v)$ loci are more apart (in other words, an increase in $\epsilon$ shifts $\Psi^{\mathrm{c}}(\mathrm{r})$ outward by more than $\left.\Psi^{\mathrm{u}}(\mathrm{r})\right)$, it means a larger differences between $\mathrm{r}^{\mathrm{u}}$ and $\mathrm{r}^{\mathrm{c}}$. Other results follow in a similar fashion.

\section{Figure A: Comparison between Unconstrained and Constrained Equilibrium}

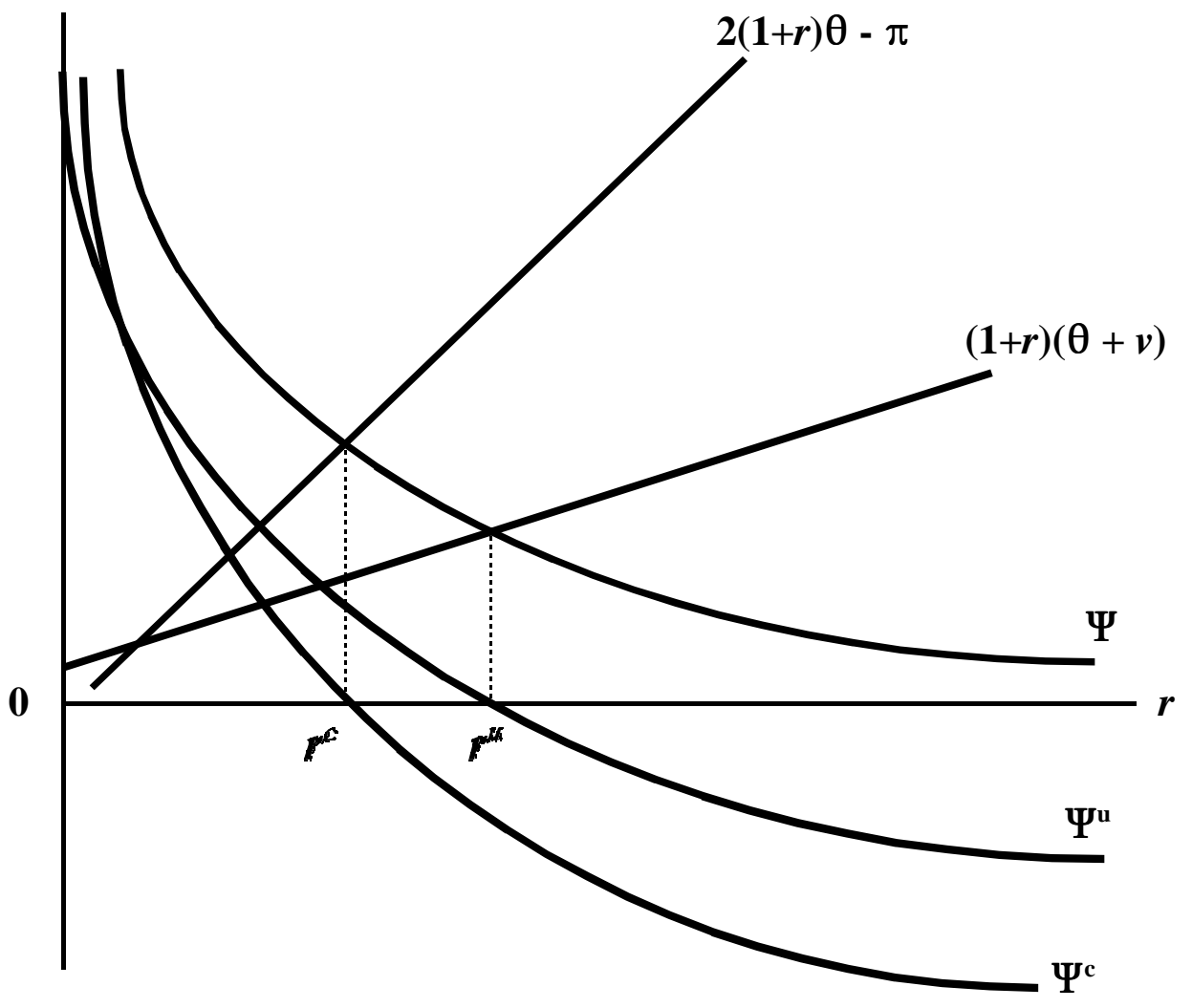

